\title{
The recent decline in employment dynamics
}

\author{
Henry R Hyatt ${ }^{1}$ and James R Spletzer ${ }^{2^{*}}$
}

\author{
* Correspondence: \\ James.R.Spletzer@census.gov \\ ${ }^{2}$ Center for Economic Studies, U.S. \\ Census Bureau, and IZA, 4600 Silver \\ Hill Road, ACSD HQ-5K175, \\ Washington DC 20233, USA \\ Full list of author information is \\ available at the end of the article
}

\begin{abstract}
We document and attempt to explain the recent decline in employment dynamics in the U.S. We have four major empirical findings. First, each measure exhibits a "stair step" pattern, with the declines concentrated in recessions and little increase during subsequent expansions. Second, changes in the composition of workers and businesses can explain only a small amount of the decline. Third, any explanation for the decline in job creation and job destruction will account for no more than onethird of the decline in hires and separations. Fourth, the decline in hires and separations is driven by the disappearance of short-duration jobs.

JEL Codes: E24, J63

Keywords: Hires; Separations; Job creation; Job destruction; Job-to-job flows
\end{abstract}

\section{Introduction}

Over the course of the last two decades, an increasing number of sources have provided data on the rate at which jobs and workers move across employers. One consistent story these data tell is that employment dynamics in the United States exhibit double-digit declines during the first decade of the twenty-first century. ${ }^{1}$ This is the case across multiple measures and data sources, and we summarize these declines in Table 1 (we describe the data in the next section). ${ }^{2}$ While the levels of each measure differ across data sources due to a variety of definitional and scope differences, there is a strong agreement in the trend for each measure. Between 1998 and 2010, hires and separations rates fell between 10 percent and 38 percent, depending upon the data source. Job creation and job destruction rates declined by roughly 22 to 33 percent. Job-to-job flows exhibited the largest decline, falling by 47 to 53 percent. Available evidence suggests that the 1998-2010 decline in employment dynamics is an acceleration of a downward trend in employment dynamics that extends backwards in time before the start of our data series. ${ }^{3}$

Employment dynamics are important. Increases in job and worker reallocation have been associated with higher economic growth by, among others, Jovanovic and Moffitt (1990) and Foster, Haltiwanger, and Krizan (2001). This positive association comes through the Schumpeterian creative destruction process of new and expanding businesses replacing the market share of established companies, as well as the ongoing efforts of businesses and workers seeking their most productive matches. There is also strong evidence that job switching is an important component of wage growth, particularly for young persons, see Topel and Ward (1992). If the decline in employment dynamics is indicative of declining innovation or declining labor market flexibility, then

(C) 2013 Hyatt and Spletzer; licensee Springer. This is an Open Access article distributed under the terms of the Creative Commons Attribution License (http://creativecommons.org/licenses/by/2.0), which permits unrestricted use, distribution, and reproduction in any medium, provided the original work is properly cited. 
Table 1 The recent decline in employment dynamics, 1998-2010*

\begin{tabular}{|c|c|c|c|c|c|}
\hline Measure & Definition & Source & Rate in $1998^{*}$ & Rate in 2010 & $\begin{array}{l}\text { Proportionate } \\
\text { decline }\end{array}$ \\
\hline \multirow[t]{3}{*}{ Hires } & \multirow{3}{*}{$\begin{array}{c}\text { New employer-employee } \\
\text { matches }\end{array}$} & LEHD & $28.1 \%$ & $18.7 \%$ & $-38 \%$ \\
\hline & & JOLTS $^{*}$ & $14.1 \%$ & $10.6 \%$ & $-28 \%$ \\
\hline & & CPS & $19.4 \%$ & $17.3 \%$ & $-11 \%$ \\
\hline \multirow[t]{3}{*}{ Separations } & \multirow{3}{*}{$\begin{array}{l}\text { Ending employer-employee } \\
\text { matches }\end{array}$} & LEHD & $26.6 \%$ & $18.5 \%$ & $-36 \%$ \\
\hline & & JOLTS ${ }^{*}$ & $14.3 \%$ & $10.1 \%$ & $-34 \%$ \\
\hline & & CPS & $19.1 \%$ & $17.2 \%$ & $-10 \%$ \\
\hline \multirow[t]{2}{*}{ Job creation } & \multirow{2}{*}{$\begin{array}{l}\text { Employment growth at new } \\
\text { and expanding establishments }\end{array}$} & LEHD & $7.7 \%$ & $5.5 \%$ & $-33 \%$ \\
\hline & & BED & $8.3 \%$ & $6.6 \%$ & $-23 \%$ \\
\hline \multirow[t]{2}{*}{ Job destruction } & \multirow{2}{*}{$\begin{array}{l}\text { Employment decline at contracting } \\
\text { and exiting establishments }\end{array}$} & LEHD & $6.4 \%$ & $5.1 \%$ & $-23 \%$ \\
\hline & & BED & $7.6 \%$ & $6.1 \%$ & $-22 \%$ \\
\hline \multirow[t]{2}{*}{ Job-to-job flows } & \multirow{2}{*}{$\begin{array}{l}\text { Direct worker movements } \\
\text { between employers }\end{array}$} & LEHD & $9.9 \%$ & $6.1 \%$ & $-47 \%$ \\
\hline & & CPS & $7.9 \%$ & $4.6 \%$ & $-53 \%$ \\
\hline
\end{tabular}

Notes: LEHD data on hires, separations, job creation, and job destruction for 30 states were downloaded from the Cornell Virtual RDC. LEHD data on job-to-job flows are from Hyatt and McEntarfer (2012b). JOLTS national monthly data were downloaded from the BLS website and converted to a quarterly frequency. BED national data were downloaded from the BLS website. CPS national monthly data were downloaded from the Federal Reserve website and converted to a quarterly frequency. 1998 refers to 1998:Q2, 2010 to 2010:Q4, except for JOLTS data, as noted below. All data are seasonally adjusted. Proportionate declines from date $A$ to $B$ are calculated according to $100^{*}(B-A) /((A+B) / 2)$.

* Due to data availability, the initial JOLTS rate refers to 2001:Q1 rather than 1998:Q2.

this would be worrisome for the U.S. economy. On the other hand, declining dynamics could be indicative of increased job stability or reduced uncertainty.

There are numerous potential explanations for the recent decline in employment dynamics. One set of explanations concern the changes in the composition of the employed or of employers. For example, the postwar baby boom generation is aging and the employment-to-population ratio of teenagers has been falling: both of these changes should lead to reduced dynamics as the workforce shifts from subpopulations with high rates of mobility to subpopulations with low rates of mobility. Other possible explanations include declining worker mobility resulting from better initial worker-firm matching, a shift in the distribution of outside wage offers, increased mobility costs or employment adjustment costs, or the globalization of the production process. In this paper, we give the range of explanations our critical consideration.

We begin this paper by thoroughly documenting the decline in employment dynamics. ${ }^{4}$ Our empirical work relies on four leading datasets on employment dynamics in the United States: the Longitudinal Employer-Household Dynamics (LEHD), the Business Employment Dynamics (BED), the Job Openings and Labor Turnover Survey (JOLTS), and the Current Population Survey (CPS). In section III, we examine changes in labor market composition as an explanation for these declines; our analysis shows that changes in the composition of workers and businesses can explain only a small amount of the decline in employment dynamics.

In section IV, we analyze the decline in gross worker flows (hires and separations), employing some helpful identities that relate gross worker flows to gross job flows (job creation and job destruction), as well as to job-to-job flows. We find that the decline in gross job flows can be described as a narrowing of the distribution of employer growth rates, but this change in the distribution of gross job flows only explains about a third of the decline in gross worker flows. This implies that whatever economic forces are 
driving the declines in gross job flows, there are different forces that are driving the declines in gross worker flows. Analyzing the relationship between gross worker flows and job-to-job flows, we find that declines in both short-duration jobs and job-to-job flows are driving the declines in gross worker flows.

We end this paper with a discussion of economic explanations for the decline in labor market dynamics, including increases in adjustment costs, changes in the job matching process, the role of uncertainty, changes in the production process, and joband housing-lock. While we are able to rule out some explanations, we do not conduct any formal tests, and we view our discussion as an aid for future research.

\section{Empirical measures of employment dynamics}

We use data from four sources: the LEHD, the BED, the JOLTS, and the CPS. We use publicly available data whenever possible in the analysis that follows, with the exception of job-to-job flows tabulations constructed from the confidential LEHD microdata. We report data from each of our four sources on a quarterly frequency, seasonally adjusted, as rates. ${ }^{5}$ The subsections below contain short descriptions of the four datasets. A more detailed description of the data and the employment dynamics series available from each of the four data sources is provided in Hyatt and Spletzer (2013).

\section{Ila. Longitudinal Employer-Household Dynamics (LEHD)}

The LEHD is a longitudinally linked employer-employee dataset created by the U.S. Census Bureau as part of the Local Employment Dynamics federal-state partnership; see Abowd et al. (2009). The data are derived from state-submitted Unemployment Insurance (UI) wage records and the Quarterly Census of Employment and Wages (QCEW) data. Every quarter, employers who are subject to state UI laws (approximately 98\% of all private sector employers, plus state and local governments) submit to the states information on their workers (the wage records) and their workplaces (the QCEW). The wage records and the QCEW data submitted by the states to the U.S. Census Bureau are enhanced with census and survey microdata in order to incorporate information about worker demographics (age, gender, race and ethnicity, and education) and the firm (firm age and firm size).

We use quarterly measures of hires, separations, job creation, and job destruction downloaded from the Cornell Virtual RDC. Because states have joined the LEHD program at different times, and have provided various amounts of historical data upon joining the LEHD program, the length of the time series of LEHD data varies by state. We downloaded private sector data from 30 states that have data available from 1998:Q2 through 2010:Q4. These 30 states account for about 65 percent of national employment. ${ }^{6}$

Hyatt and McEntarfer (2012a, 2012b) provide job-to-job flow statistics from the confidential LEHD microdata that measure movements between dominant jobs, where the dominant job is defined as the job with the highest earnings in the quarter. The Hyatt and McEntarfer job-to-job flow statistics are computed from a sample of individuals who ever worked in at least one of nine states, and their employment histories are tracked through all available states. Movements into and out of state and local (but not federal) government jobs are included in the job-to-job flow series. ${ }^{7}$ We use the Hyatt 
and McEntarfer data in this paper; a public-use job-to-job flows data product is under development at the time of this writing.

\section{Ilb. Business Employment Dynamics (BED)}

The BED statistics on job creation and job destruction are available from the BLS website. The BED data are constructed by longitudinally linking the establishment-level QCEW microdata provided by the states (the same establishment-level data used in the creation of the LEHD data). The BED time series begins in 1992:Q3.

\section{Ilc. Job Openings and Labor Turnover Survey (JOLTS)}

The JOLTS statistics on hires and separations are available from the BLS website. The JOLTS data are constructed from a monthly survey of 16,000 establishments (the JOLTS survey form is at http://stats.bls.gov/jlt/jltc1.pdf). The JOLTS monthly data are available from December 2000 to the present. We create quarterly data from the monthly JOLTS data, with a time series that begins in 2001:Q1.

\section{Ild. Current Population Survey (CPS)}

The CPS is the workhorse data of labor economics research, with monthly information on labor force status (employed, unemployed, or not in the labor force) by a variety of demographic characteristics. We use the longitudinal CPS data created by Fallick and Fleischman (2004), who utilize the CPS microdata to calculate monthly job-to-job flow statistics. They exploit the 1994 CPS questionnaire redesign, which replaced the paper and pencil questionnaire with computer assisted interviewing. Computer assisted interviewing allows information from the previous month's interview to be available to the interviewer, and respondents are asked whether they worked for the same employer a direct measure of job-to-job change. We use the Fallick and Fleischman monthly data on job-to-job flows, as well as the hires and separations rates that result by adding the gross flows data on transitions into and out of employment. We aggregate the monthly data to quarterly.

\section{The effect of composition changes on the decline in employment dynamics}

We now turn to a decomposition of the decline in employment dynamics for each measure and data source under consideration. The basic question we seek to answer is, "how much of the decline is due to the changing composition of individuals or businesses?" For example, as the baby boom has been aging during the last 15 years, the share of employment of workers aged 25-44 has been declining (from 53.1 percent in 1998:Q2 to 43.9 percent in 2010:Q4), while the employment share of workers aged 4564 has been increasing (from 27.5 percent in 1998:Q2 to 37.0 percent in 2010:Q4). Because the hires and separations rate are essentially monotonically declining in age, the aging of the workforce will lead to declining hires and separations rates.

We measure the effect of composition changes using a standard decomposition technique to separate between-group differences from trends within groups for any employment dynamics measure $Y$, as follows. Any measure of employment dynamics $Y_{t}$ can be written as $\sum_{\mathrm{i}} \mathrm{Y}_{\mathrm{it}} \mathrm{S}_{\mathrm{i}}$, where $\mathrm{i}$ indexes groups of the workforce or businesses (such as 
worker age or firm size), and $S_{\mathrm{i}}$ is the share of the group. We decompose the difference $\Delta \mathrm{Y}_{\mathrm{t}}=\mathrm{Y}_{\mathrm{t}}-\mathrm{Y}_{\mathrm{t}-1}$ according to

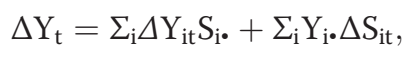

where $\mathrm{Y}_{\mathrm{i}}$. denotes the mean such that $\mathrm{Y}_{\mathrm{i}}=\left(\mathrm{Y}_{\mathrm{it}}+\mathrm{Y}_{\mathrm{it}-1}\right) / 2$, and likewise $\mathrm{S}_{\mathrm{i}}$. In words, the decline in employment dynamics is equal to the change in the dynamics of each group weighted by the group's average employment share (the "within" effect) plus the change in each group's employment share weighted by the group's average measure of dynamics (the "composition" effect).

\section{IIla. Hires and separations}

Figure 1 presents the seasonally adjusted rates of hires and separations in three data sources: the LEHD, the JOLTS, and the CPS. The levels of hires and separations are clearly different across data sources, but this is not a serious concern. There is evidence that the LEHD has more short-duration jobs than does the CPS (see Abraham et al. 2013), and this would lead to higher LEHD hires and separations rates. There is also evidence that the JOLTS misses establishments with large amounts of dynamics (see Davis et al. 2010b), which would lead to lower JOLTS hires and separations rates. More importantly, we see declining rates of hires and separations in all three datasets, albeit varying amounts of decline. These declines are not sensitive to the endpoints of the time period; declines are obvious in Figure 1 from any point in the late 1990s (excepting the JOLTS, which starts in 2001:Q1) to any point in the late 2000's.

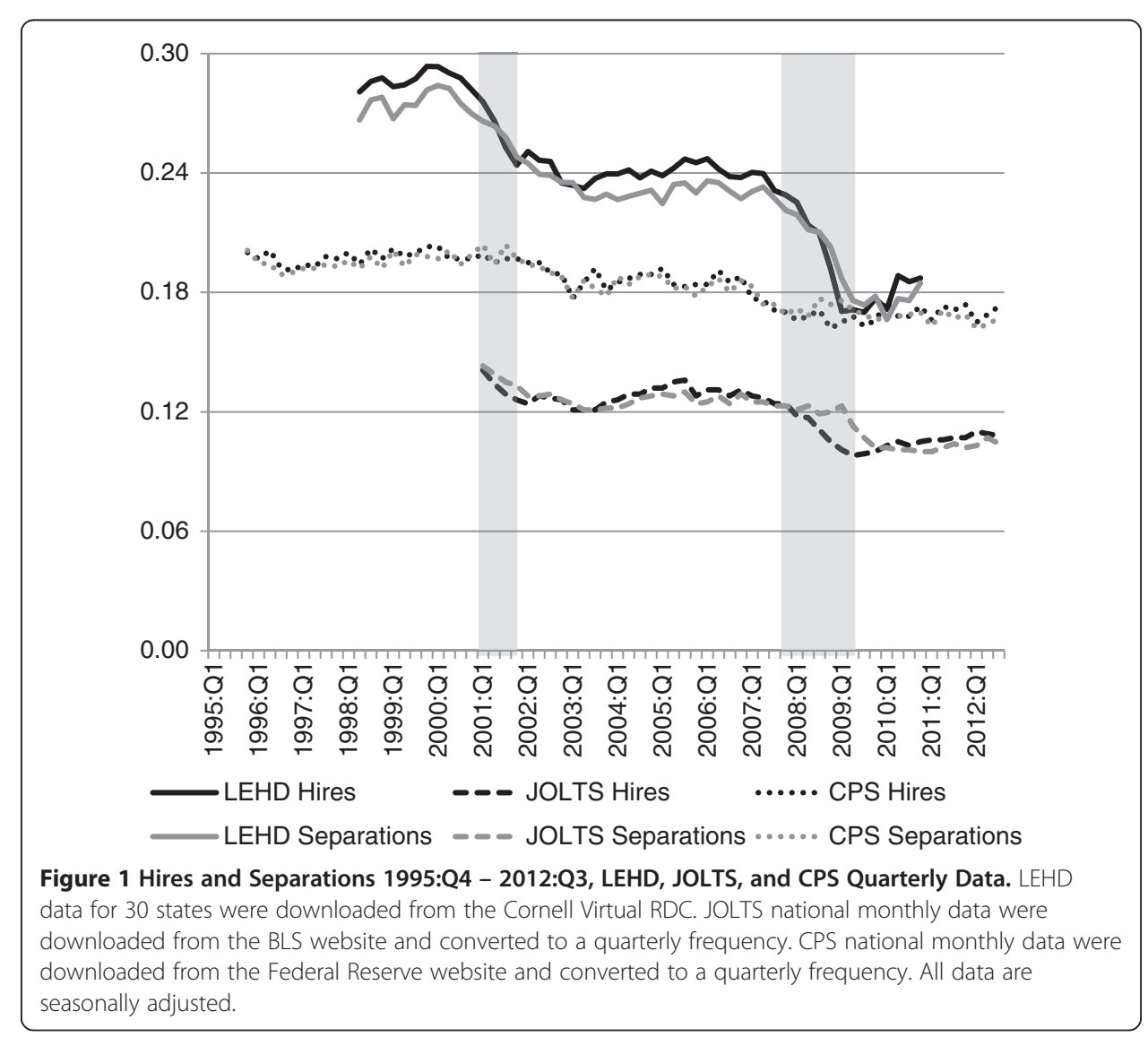


The decline in hires and separations from all three data sources shows a "stair-step" pattern, with declines concentrated in or around recessions, from which the measures never fully recover during expansions. Using NBER recession dates, all of the 8.9 percentage point decline in LEHD hires (from 2001:Q1 - 2010:Q4) occurs during the 2001 and the 2007-2009 recessions, and 6.3 percentage points of the 8.1 percentage point decline in LEHD separations occurs during the recessionary quarters. Similarly, more than all of the decline in JOLTS hires occurs during recessions, and half of the decline in JOLTS separations occurs during recessions. The CPS series is somewhat different: as seen in Figure 1, much of the decline in CPS hires and separations occurs in 2002, immediately following the 2001 recession, and in 2007, immediately preceding the 2007-2009 recession.

The top rows of Table 2 document the 2001:Q1 - 2010:Q4 decline in hires and separations from the three data sources. The decomposition results begin in the middle of Table $2 .^{8}$ The decompositions show that changes in the age distribution towards older workers explain 13 and 11 percent, respectively, of the decline in hires and separations in the LEHD, and 23 and 15 percent of the decline in the CPS. It is not surprising to find essentially no effects for gender, given there have been only small changes in the gender composition of the workforce during the 2001 - 2010 time period and the differences in employment dynamics by gender are small. Although there have been noticeable changes in the race and ethnicity composition of the workforce between 2001 and $2010,{ }^{9}$ the total composition effect of race and ethnicity on declining employment dynamics is negligible, and actually goes the wrong way. The CPS shows that changes in the education distribution explain about a quarter of the decline in hires and separations, which reflects the fact that the proportion of the U.S. labor force that has a Bachelor's degree has been increasing, and workers with college degrees tend to have more stable employment than workers without college degrees. ${ }^{10}$

Table 2 Hires and separations decomposition by individual and business characteristics 2001:Q1 - 2010:Q4, LEHD, JOLTS, and CPS quarterly data

\begin{tabular}{|c|c|c|c|c|c|c|}
\hline & $\begin{array}{l}\text { LEHD } \\
\text { Hires }\end{array}$ & $\begin{array}{c}\text { LEHD } \\
\text { Separations }\end{array}$ & $\begin{array}{l}\text { JOLTS } \\
\text { Hires }\end{array}$ & $\begin{array}{c}\text { JOLTS } \\
\text { Separations }\end{array}$ & $\begin{array}{l}\text { CPS } \\
\text { Hires }\end{array}$ & $\begin{array}{c}\text { CPS } \\
\text { Separations }\end{array}$ \\
\hline $2001: Q 1$ & .276 & .266 & .141 & .143 & .199 & .204 \\
\hline 2010:Q4 & .187 & .185 & .106 & .101 & .173 & .172 \\
\hline Change & -.089 & -.081 & -.035 & -.042 & -.026 & -.032 \\
\hline \multicolumn{7}{|c|}{$\%$ of decline explained by } \\
\hline Worker age & $12.6 \%$ & $11.2 \%$ & & & $23.3 \%$ & $15.0 \%$ \\
\hline Gender & $0.2 \%$ & $0.2 \%$ & & & $-0.3 \%$ & $-0.3 \%$ \\
\hline Race - ethnicity & $-1.8 \%$ & $-1.7 \%$ & & & & \\
\hline Education & $-0.4 \%$ & $-0.4 \%$ & & & $23.2 \%$ & $25.4 \%$ \\
\hline Industry & $-6.3 \%$ & $-5.8 \%$ & $-2.6 \%$ & $-1.4 \%$ & $-4.4 \%$ & $-3.5 \%$ \\
\hline Firm size & $2.4 \%$ & $2.3 \%$ & & & & \\
\hline Estab size & & & $-0.7 \%$ & $-0.7 \%$ & & \\
\hline Firm age & $8.4 \%$ & $7.5 \%$ & & & & \\
\hline
\end{tabular}

Notes: LEHD data for 30 states were downloaded from the Cornell Virtual RDC. JOLTS national monthly data by industry were downloaded from the BLS website and converted to a quarterly frequency. JOLTS national monthly data by establishment size are available upon request from BLS. CPS national monthly data were downloaded from the Federal Reserve website and converted to a quarterly frequency. CPS data by demographic and business characteristics were provided by Bruce Fallick. All data are seasonally adjusted. 
Each of the decompositions for age, gender, race and ethnicity, and education in Table 2 (and in all other tables) are separate decompositions. For two reasons, we have chosen not to conduct a decomposition with interactions of the demographic characteristics. First, every decomposition in Table 2 (and Table 3, as well as the decompositions using CPS data in Table 4) is done from public-use data, and the public-use data do not contain any interactions. Second, the results in Decker et.al. (2013) suggest that fully interacted decompositions are roughly cumulative; this implies that the small gender effect and the negative race and ethnicity effect would explain less of the declining dynamics than just age alone.

We see in the last several rows of Table 2 that employer characteristics such as industry and the size of the business explain relatively little of the decline in hires and separations. In all three datasets, the LEHD, the JOLTS, and the CPS, changes in industry composition lead to higher employment dynamics. Much of this is due to the decline in the construction industry after the housing bust of 2006 (the construction industry has high rates of employment dynamics), and the longer-run shift in employment from manufacturing (an industry with low rates of employment dynamics) to healthcare and accommodation and food services (the latter industry has high rates of employment dynamics). Of the various employer characteristics, the shift in the firm age distribution toward older firms has the largest effect, explaining roughly 8 percent of the decline in hires and separations. ${ }^{11}$

\section{IIIb. Job creation and job destruction}

Quarterly measures of job creation and job destruction are available from the LEHD and the BED. Figure 2 presents the seasonally adjusted time series for these measures. Again, we see a clear decline in the rates of job creation and job destruction between the 1990s and the 2000s, although the countercyclical nature of job destruction leads to less of a "stair-step" pattern around recessions than is seen for hires, separations, and job creation. Table 3 presents the decompositions by employer characteristics (industry, firm size, and firm age). Similar to the results in Table 2, the changing composition of industrial employment goes the wrong way in that it predicts rising rates of job creation and job destruction. The changing composition of firm size, towards larger firms, explains 10 and 13 percent, respectively, of the decline in LEHD job creation and

Table 3 Job creation and job destruction decomposition by business characteristics 1998:Q2 - 2010:Q4, LEHD and BED quarterly data

\begin{tabular}{lcccc}
\hline & LEHD Job creation & LEHD Job destruction & BED Job creation & BED Job destruction \\
\hline 1998:Q2 & .077 & .064 & .083 & .076 \\
2010:Q4 & .055 & .051 & .066 & .061 \\
Change & -.022 & -.013 & -.017 & -.015 \\
\% of decline & & & & \\
explained by: & & & $-9.0 \%$ & $-5.9 \%$ \\
$\quad$ Industry & $-7.2 \%$ & $-9.7 \%$ & $5.8 \%$ & $6.3 \%$ \\
Firm size & $9.6 \%$ & $13.1 \%$ & & \\
Firm age & $18.9 \%$ & $14.4 \%$ & & \\
\hline
\end{tabular}

Notes: LEHD data for 30 states were downloaded from the Cornell Virtual RDC. BED national data were downloaded from the BLS website. BED establishment level data are different than BED firm level data; the BED job creation and job destruction statistics in the top rows of this table are national establishment level data. All data are seasonally adjusted. 
Table 4 Job-to-job flows decomposition by individual and business characteristics 1998: Q2 - 2010:Q4, LEHD and CPS quarterly data

\begin{tabular}{lcc}
\hline & LEHD & CPS \\
& Job-to-job & Job-to-job \\
\hline 1998:Q2 & .099 & .079 \\
2010:Q4 & .061 & .046 \\
Change & -.038 & -.033 \\
\% of decline explained by & & \\
Worker age & $21.0 \%$ & $9.0 \%$ \\
Gender & $0.3 \%$ & $0.0 \%$ \\
Race \& ethnicity & $-0.6 \%$ & \\
Education & $-0.2 \%$ & $2.9 \%$ \\
Industry & $-1.3 \%$ & $-1.1 \%$ \\
Firm size & $2.8 \%$ & \\
Firm age & $7.6 \%$ & \\
\hline
\end{tabular}

Notes: LEHD data are from Hyatt and McEntarfer (2012b). CPS national monthly data were downloaded from the Federal Reserve website and converted to a quarterly frequency. CPS data by demographic and business characteristics were provided by Bruce Fallick. All data are seasonally adjusted.

job destruction, and about 6 percent of the decline in each of the corresponding BED measures. The changing composition by firm age again has the largest estimated magnitude, explaining 19 percent of the decline in job creation and 14 percent of the decline in job destruction.

IIlc. Job-to-job flows

Job-to-job flows can be calculated from two datasets: the LEHD and the CPS. Figure 3 presents the two seasonally adjusted quarterly time series. We see, similar to the other series, that much of the decline in job-to-job flows occurs during or around recessions, and that during the expansion between 2001 and 2007 job-to-job flow rates never recover to the level seen during the 1990s. Using NBER recession dates, more than all of the 3.8 percentage point decline in the LEHD measure occurs during recessions, and 2.0 percentage points of the 3.3 percentage point decline in the CPS measure occurs during recessions. The decomposition results for job-to-job flows are presented in Table 4. Changes in demographic and business composition do very little to explain the decline in job-to-job flow rates. Of any characteristic, only worker age and firm age explains more than a few percent of the decline in job-to-job flow rates.

\section{Additional aspects of the decline}

The data presented in the previous section shows overwhelming evidence that measures of employment dynamics (hires, separations, job creation, job destruction, and job-to-job flows) have declined during the 1998-2010 time period. These declines occur in all datasets in which we measure quarterly employment dynamics. Furthermore, we have shown that the changing composition of any worker characteristic or business characteristic during the time period can explain at most a quarter of the decline. In this section, we explore the identities between the measures of employment dynamics to better understand the nature of the decline. 


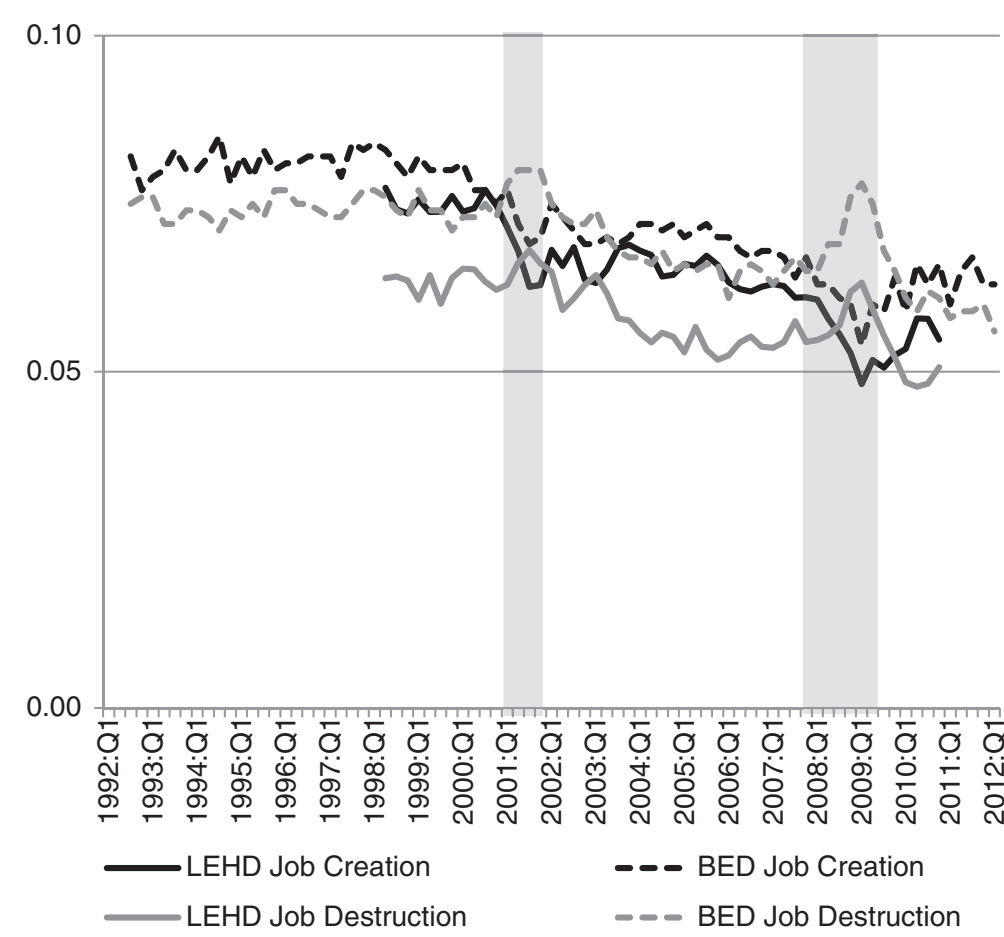

Figure 2 Job Creation and job destruction 1992:Q3 - 2012:Q1, LEHD and BED quarterly data. LEHD data for 30 states were downloaded from the Cornell Virtual RDC. BED national data were downloaded from the BLS website. All data are seasonally adjusted.

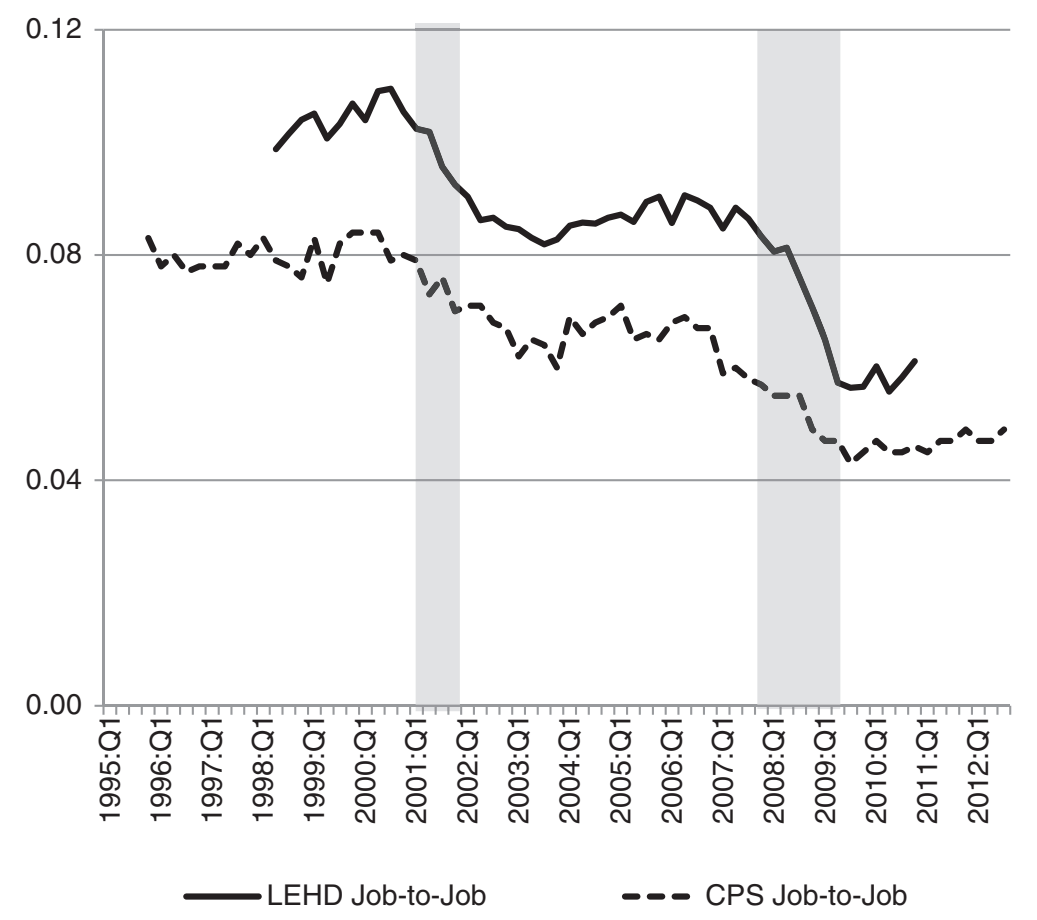

Figure 3 Job-to-job Flows 1995:Q4 - 2012:Q3, LEHD and CPS quarterly data. LEHD data are from Hyatt and McEntarfer (2012b). CPS national monthly data were downloaded from the Federal Reserve website and converted to a quarterly frequency. All data are seasonally adjusted. 


\section{IVa. Gross worker flows and gross job flows}

Hires and separations are the necessary consequence of both job creation and job destruction. Each expanding employer necessarily must hire at least as many workers as required for their employment count to increase, although they often hire more employees in order to replace workers who separate. Similarly, contracting employers often have more separations than the size of the contraction. The difference between hires and job creation is called churn, which is also the difference between separations and job destruction. This can be written as:

$$
\text { Hires }+ \text { Separations }=\text { Job Creation }+ \text { Job Destruction }+2 * \text { Churn }
$$

In this identity, job creation and job destruction measure the reallocation of jobs across businesses or the "between establishment" employment reallocations, while churn measures the "within-establishment" reallocation of workers.

This identity provides a natural starting point for explaining how the decline in gross worker flows is related to the decline in gross job flows. We show the results of this identity in in Table 5 for two data sources. In the LEHD data, we find that 16.5 percent of the decline in hires and separations from 2001:Q1 to 2010:Q4 is associated with a decline in job creation and job destruction, whereas 83.5 percent is associated with a decline in churn. The JOLTS data used by Lazear and Spletzer (2012) tell a broadly similar story: little (9.6 percent) of the decline in worker flows is accounted for by a decline in job creation and job destruction, whereas most of the decline ( 90.4 percent) is accounted for by a decline in churn.

Because the relationship between gross worker flows and gross job flows is highly nonlinear, this simple decomposition may not be the appropriate method of accounting for the relationship between the two. To address this possible concern, we estimate the basic compositional analysis from the previous section with another characteristic of employers: the employer's growth rate. We use the growth measure " $\mathrm{g}$ " defined by Davis, Haltiwanger, and Schuh (1996), where $E$ is employment and $g_{t}=\left(E_{t}-E_{t-1}\right) /\left[\left(E_{t}+E_{t-1}\right) / 2\right]$. We create 55 growth rate bins: one bin for deaths $\left(g_{t}=-2\right), 26$ bins of various sizes for contractions $\left(-2<g_{t}<0\right)$, one bin for no growth $\left(g_{t}=0\right), 26$ bins of various sizes for expansions $\left(0<g_{t}<2\right)$, and one bin for births $\left(g_{t}=2\right){ }^{12}$

Table 6 contains the results for the decomposition of employment dynamics using the establishment growth rates in the LEHD data (we are now computing estimates

Table 5 Gross worker and job flows

\begin{tabular}{|c|c|c|c|c|}
\hline & 2001:Q1 & 2010:Q4 & Change & Percent of $\mathrm{H}+\mathrm{S}$ Change \\
\hline \multicolumn{5}{|l|}{$\underline{\text { LEHD }}$} \\
\hline $\mathrm{H}+\mathrm{S}$ & .542 & .372 & -.170 & \\
\hline$J C+J D$ & .134 & .106 & -.028 & $16.5 \%$ \\
\hline $2^{*}$ Churn & .408 & .266 & -.142 & $83.5 \%$ \\
\hline \multicolumn{5}{|l|}{$\underline{\mathrm{JOLTS}}$} \\
\hline $\mathrm{H}+\mathrm{S}$ & .222 & .170 & -.052 & \\
\hline$J C+J D$ & .075 & .070 & -.005 & $9.6 \%$ \\
\hline $2 *$ Churn & .147 & .100 & -.047 & $90.4 \%$ \\
\hline
\end{tabular}

Notes: LEHD data on hires, separations, job creation, and job destruction for 30 states were downloaded from the Cornell Virtual RDC. JOLTS data on hires, separations, job creation, and job destruction data are from the Lazear and Spletzer (2012) analysis of the JOLTS microdata. All data are seasonally adjusted. 
Table 6 Employment dynamics decomposition by business characteristics 1998:Q2 2010:Q4, LEHD quarterly data

\begin{tabular}{lcccc}
\hline & Job creation & Job destruction & Hires & Separations \\
\hline 1998:Q2 & .072 & .065 & .267 & .260 \\
2010:Q4 & .052 & .052 & .175 & .175 \\
Change & -.020 & -.013 & -.092 & -.084 \\
\% of change explained by & & & $37.3 \%$ & $32.0 \%$ \\
$\quad$ Emp growth & $99.8 \%$ & $100.3 \%$ & & \\
\hline Notes: Authors' tabulation of LEHD microdata. Data are seasonally adjusted.
\end{tabular}

from the confidential LEHD microdata rather than using publicly available data). To interpret the results in the table, it is helpful to review the decomposition, $\Delta \mathrm{Y}_{\mathrm{t}}=\Sigma_{\mathrm{g}} \Delta \mathrm{Y}_{\mathrm{gt}} \mathrm{S}_{\mathrm{g}}+$ $\Sigma_{\mathrm{g}} \mathrm{Y}_{\mathrm{g}} \Delta \mathrm{S}_{\mathrm{gg}}$, where $\mathrm{g}$ is the establishment's growth rate and $\mathrm{S}_{\mathrm{g}}$ is the employment share in the $\mathrm{g}^{\text {th }}$ interval. If $\mathrm{Y}$ refers to job creation or job destruction and if $\mathrm{g}$ were defined very precisely as exact point estimates, then $\Delta \mathrm{Y}_{\mathrm{gt}}$ would be zero by definition and $100 \%$ of the decline in job creation and job destruction would be attributable to changes in employment shares across the establishment growth rate distribution $\left(\Delta \mathrm{S}_{\mathrm{gt}}\right)$. Our estimates of the composition effect for job creation and job destruction in Table 6 are essentially 100\% (99.8\% for job creation and $100.3 \%$ for job destruction). The narrowing establishment growth rate distribution, which explains 100 percent of the decline in the job creation and job destruction rates, explains only 37.3 percent of the declining hires rate and 32.0 percent of the declining separations rate.

Changes in the rate of job creation and job destruction using the 55 growth rate bins are shown in Figure 4. Comparing 2010:Q4 to 1998:Q2, there is less employment in establishments with large expansions and births ( $\mathrm{g}>03)$ and less employment in establishments with large contractions or deaths $(\mathrm{g}<-.06)$. Figure 4 also shows that there is more employment in establishments with no change in employment: this share rises from 11.9 percent in 1998:Q2 to 14.6 percent in 2010:Q4. ${ }^{13}$ Our composition analysis in Table 3 indicates that we don't yet know the underlying forces driving the narrowing of the establishment growth rate distribution.

Table 7 Gross worker flows and job-to-job flows

\begin{tabular}{|c|c|c|c|c|}
\hline & 1998:Q2 & 2010:Q4 & Change & Percent of $\mathrm{H}+\mathrm{S}$ Change \\
\hline \multicolumn{5}{|l|}{$\underline{\mathrm{CPS}}$} \\
\hline $\mathrm{H}+\mathrm{S}$ & .385 & .345 & -.040 & \\
\hline In+Out & .227 & .253 & .026 & $-65 \%$ \\
\hline $2^{*}$ Job-to-Job & .158 & .092 & -.066 & $165 \%$ \\
\hline \multicolumn{5}{|l|}{$\underline{\mathrm{LEHD}}$} \\
\hline $\mathrm{H}+\mathrm{S}$ & .547 & .372 & -.175 & \\
\hline In+Out & .114 & .093 & -.021 & $12.0 \%$ \\
\hline $2^{*}$ Job-to-Job & .198 & .122 & -.076 & $43.4 \%$ \\
\hline Secondary and short duration job activity & .235 & .157 & -.078 & $44.6 \%$ \\
\hline
\end{tabular}

Notes: CPS national monthly data were downloaded from the Federal Reserve website and converted to a quarterly frequency. LEHD data for 30 states were downloaded from the Cornell Virtual RDC to create rates of hires and separations. LEHD job-to-job flows data are from Hyatt and McEntarfer (2012b). LEHD inflow and outflow rates were calculated as a special tabulation from the job-to-job flows database. All data are seasonally adjusted. 


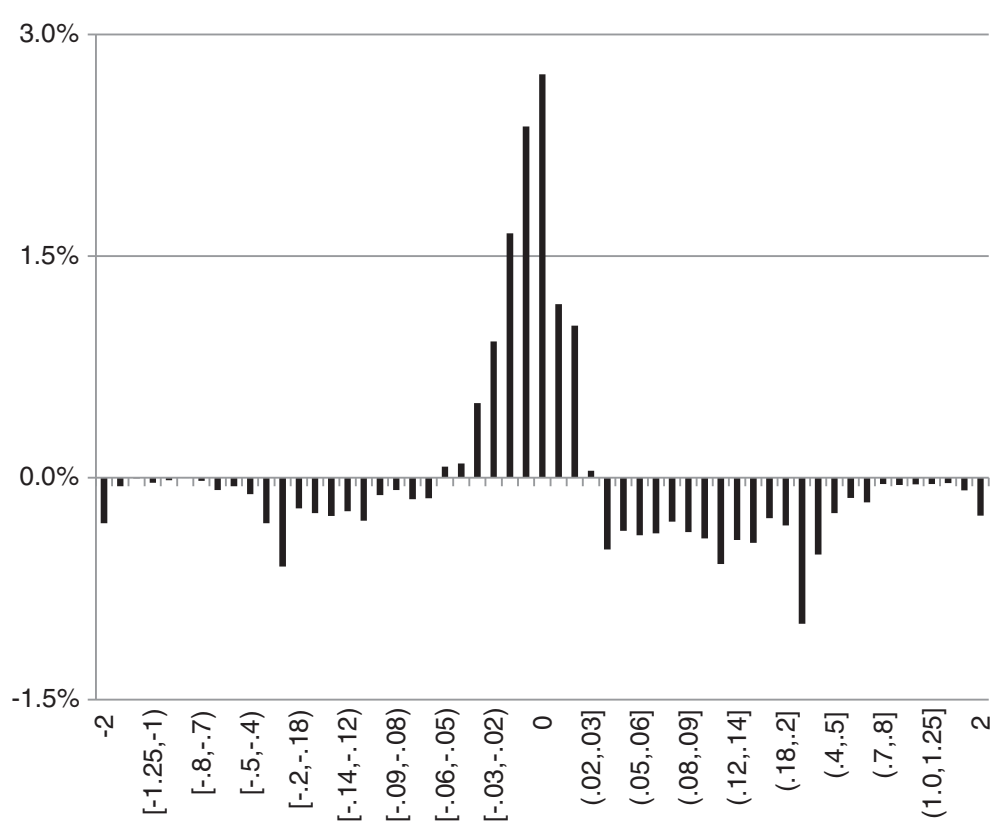

Figure 4 Change in employment share (vertical axis), by the establishment's growth rate distribution g (horizontal axis) 1998:Q2 - 2010:Q4 LEHD quarterly data. Authors' analysis of LEHD microdata. Data are seasonally adjusted.

We now ask why only a third of the decline in hires and separations can be explained by the narrowing establishment growth rate distribution evident in Figure 4. Figure 5 shows the hires and separations rates for each of the 55 employment growth intervals "g." This is the familiar "hockey-stick" graph popularized by Davis, Faberman, and Haltiwanger (2006, 2012). It is immediately obvious that the hires and separations rates have declined between 1998:Q2 and 2010:Q4 within every growth interval, which reflects a decline in churn. ${ }^{14}$ However, this relationship between job flows and workers flows in Figure 5 is mechanical, and understanding the economic forces that are driving the declining hires and separations rates remains an open area for research.

\section{IVb. Gross worker flows and job-to-job flows}

The previous subsection examined the identity linking gross worker flows and gross job flows. Another identity amongst the employment dynamics measures we analyze is that linking gross workers flows and job-to-job flows. In the simplest conceptual model, hires are defined as the sum of job-to-job flows plus employment inflows, and separations are defined as the sum of job-to-job flows plus employment outflows. This leads to:

$$
\begin{aligned}
\text { Hires }+ \text { Separations }= & \text { Employment Inflows }+ \text { Employment Outflows } \\
& +2^{*} \text { Job-to-Job Flows }
\end{aligned}
$$

In this identity, employment inflows and outflows measure the reallocation of workers across the labor force states of employed and not-employed, while job-to-job flows measures the reallocation of workers across jobs.

Empirical quantification of this equation uses the CPS summary statistics in Table 1, and is shown in Table 7. We find that 165 percent of the decline in hires and 


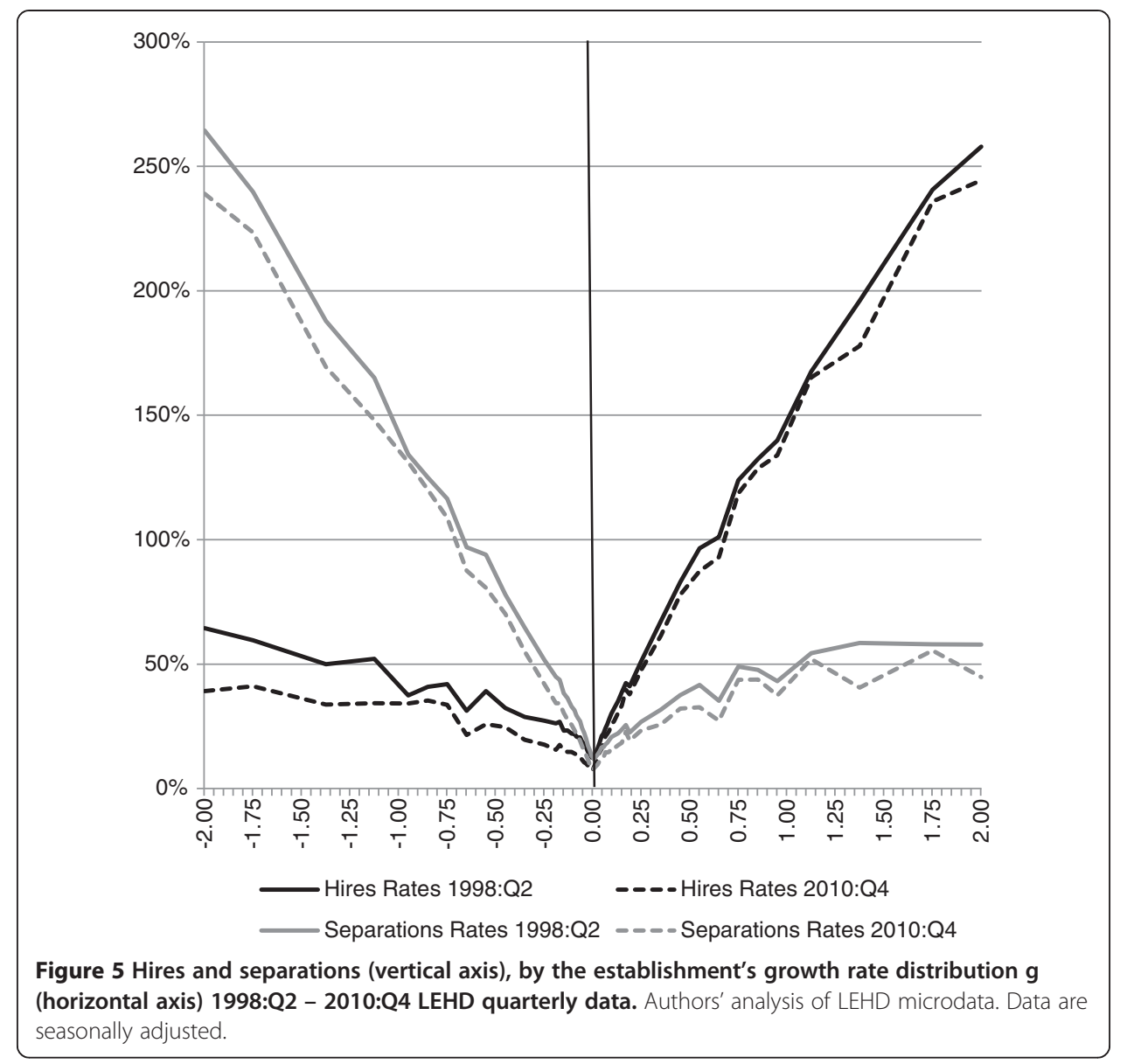

separations is associated with the decline in job-to-job flows, rather than trends in flows into and out of employment. The negative contribution of employment inflows and outflows reflects the increasing trend in these series in the CPS data between 1998: Q2 and 2010:Q4.

Quantifying an identity that relates worker flows and job-to-job flows in the LEHD data is slightly more complex. The CPS is a person-level dataset, with the most attention paid to the respondent's main job. In contrast, the LEHD tracks all jobs covered by Unemployment Insurance, including secondary jobs and any short-duration jobs that might be missed by the reference week concept in the CPS. Our measure of job-to-job flows from the LEHD is similar to the CPS, in that it measures flows across dominant jobs, whereas our measure of hires and separations from the LEHD records hires and separations from all jobs. This conceptual difference requires us to modify the identity above for use with the LEHD data, as follows:

$$
\begin{gathered}
\text { Hires }+ \text { Separations }=\text { Employment Inflows }+ \text { Employment Outflows } \\
+2 * \text { Job-to-Job Flows (dominant jobs) } \\
+ \text { Secondary and Short-Duration Job Activity }
\end{gathered}
$$

The empirical quantification of this equation using the LEHD data is also in Table 7. The hires and separations measures, as well as the job-to-job flows across dominant jobs, are from the data in Figures 1 and 3; the estimates of employment inflows and 
outflows are from tabulations of the confidential LEHD microdata. We find that 12 percent of the decline in hires and separations is associated with a decline in employment inflows and outflows, 43.4 percent is associated with job-to-job flows across dominant jobs, and the rest (44.6 percent) is associated with declines in secondary or shortduration job activity. While different from the point estimate using the CPS data (-65 percent compared to 12 percent), the two datasets are telling the same story that flows into and out of employment are not the dominant explanation for the trend decline in hires and separations. Rather, the decline in hires and separations is driven by a decline in the job-to-job flow rates as well as by declines in worker flows associated with secondary and short-duration jobs.

This importance of secondary and short-duration jobs in accounting for the decline in gross worker flows warrants further attention. In Table 8, using publicly available LEHD data, we document that the decline of hires and separations into and out of short-duration jobs (defined here as jobs that begin and end within the same calendar quarter) is responsible for 52.7 percent of the decline in gross worker flows. This tells us that any explanation for the declining hires and separations rates will need to account for a decline in short-duration jobs. In Figure 6, we show the rate of hires into these jobs that begin and end within the same quarter. The hires rate into shortduration jobs falls from 11.4 percent in 1998:Q4 to 6.0 percent in 2010:Q3. Similar to the aggregate hires series, these data in Figure 6 follow the familiar stair-step pattern of declines during and around the recessions of 2001 and 2007-2009.

\section{Discussion}

As stated in our introduction, there are many possible reasons for the recent decline in employment dynamics. In this section, we discuss strands of the economics literature that we think may provide potential avenues for addressing the source of declining dynamics.

\section{Va. Employment adjustment costs}

Labor market frictions naturally discourage the mobility of labor. These frictions are costs to the employer or employee (or both) of beginning or ending a job, or of changing jobs, such as the employer costs of hiring as well as worker costs of conducting job search. Empirical estimates of some of these costs have been surveyed recently by Manning (2011), who documents that higher skill workers have higher hiring costs than other workers. We might, therefore, speculate that recent increases in job polarization might lead to lower overall turnover. However, supplemental analysis (not shown) indicates that the greatest within-group declines by education (a proxy for skill) occur for

Table 8 Gross worker flows in the LEHD

\begin{tabular}{ccccc}
\hline LEHD & $\mathbf{1 9 9 8 : Q 4}$ & $\mathbf{2 0 1 0 : Q 3}$ & Change & Percent of H+S Change \\
\hline H+S & .566 & .361 & -.205 & \\
H+S Single quarter jobs & .228 & .120 & -.108 & $52.7 \%$ \\
H+S Two quarter jobs & .130 & .078 & -.052 & $25.4 \%$ \\
H+S Three+ quarter jobs & .208 & .163 & -.045 & $22.0 \%$ \\
\hline
\end{tabular}

Notes: LEHD data for 30 states were downloaded from the Cornell Virtual RDC. All data are seasonally adjusted. 


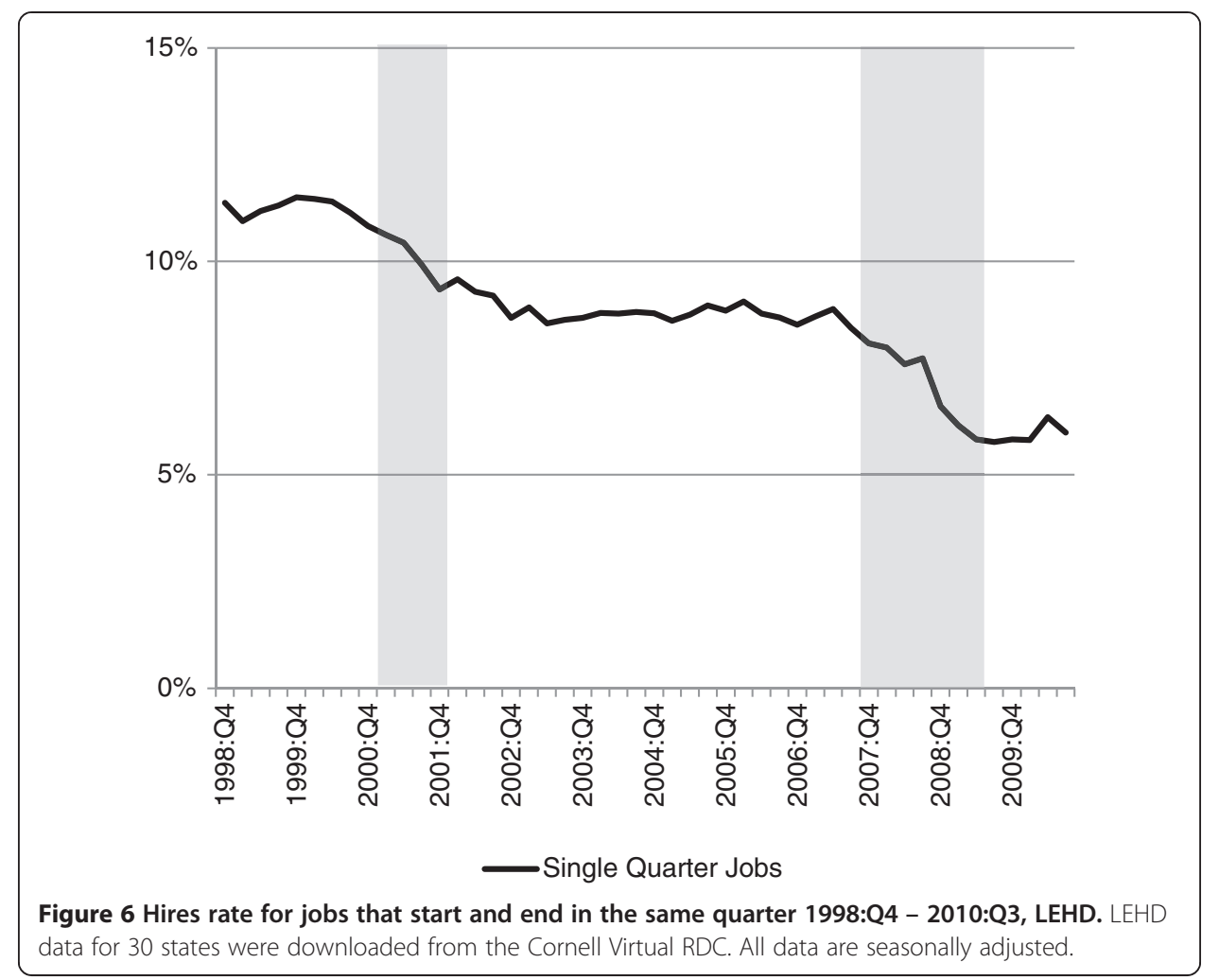

the lowest-educated workers. Another hiring costs story is that, during the last two decades, expanding use of the internet for filling jobs has likely led to lower costs of posting vacancies, and similarly the costs of applying for vacancies has likely declined as well, both of which would result in increased turnover. As discussed by Autor (2001), the direction of the effect of the internet is ambiguous. The reduction in vacancy posting and job search costs might increase match quality, which would result in less turnover.

Similar to costs associated with hiring workers, there are costs associated with laying off or firing workers, which can involve severance payments, compliance with employment laws, or legal costs associated with the risk of lawsuits; see the recent review by MacLeod (2011). We know of no such recent cost increases in the U.S. that would be a major factor contributing to declining dynamics. More generally, the main trend in the costs associated with employment separations in recent decades seems to be the continuing decline in unionization rates, which presumably makes separations less costly.

In addition to the direct costs associated with hiring and separations, there is also a well-developed literature on employment adjustment costs, including Bloom (2009) and the references therein. In addition to the costs associated with hiring and firing workers, there are organizational and other costs associated with expanding or contracting an establishment's workforce that matter when considering the costs associated with changes in employment levels. We think a fruitful avenue for research may be to estimate models that allow these comprehensive adjustment costs to vary over time. 


\section{Vb. Job matching and employment dynamics}

Numerous studies including Burdett (1978) and Jovanovic (1979) have proposed that worker-employer combinations differ in their productive output, which leads to job switching in the labor market. Changes in the nature of this job matching process can lead to changes in employment dynamics. In such models, if the match quality distribution of new job offers suddenly shifts toward having fewer high productivity matches, then fewer workers will accept job offers and so there will be less job-to-job mobility. Alternatively, if younger workers obtain better initial matches, then there will be less subsequent mobility and more long-tenure jobs. It may be possible to distinguish between these explanations by examining the careers and tenure patterns of younger workers. Molloy, Smith, and Wozniak (2013) is a promising start on such an empirical analysis.

It is critical to note that the declines in employment dynamics are concentrated in recessions. During recessions, lower demand leads to fewer opportunities that are more productive than the existing match. Moscarini and Postel-Vinay (2013) show that a wage posting model can produce procyclical gross worker flows and job-to-job flows. However, it is less obvious why there would be a dramatic long-run downward trend in these measures. What is more plausible is the idea that in recessions, there may be fewer opportunities for productivity growth through reallocation across sectors of the economy. We think recent search and matching models that include on-the-job search, such as Michau (2013) and Miyamoto and Takahashi (2011), could be helpful frameworks for further understanding the declines we document.

\section{Vc. Uncertainty}

Employment dynamics are also a feature of business life cycle models such as Jovanovic (1982). New employers may be unaware of their true productivity, or have only a weak signal of their long-run profitability, and, therefore, may only know their optimal size with some error. If there are declines in the sources of uncertainty, then this will lead to lower amounts of employment dynamics within young firms relative to older firms. The LEHD data we analyzed in Table 3 show the opposite - the job creation and job destruction rates for the youngest establishments haven't changed over time, whereas the observed declines in job creation and job destruction occur for establishments that are more than 1 year old.

The fact that almost all of the declines in employment dynamics occur during recessions suggests that models emphasizing uncertainty will play a key role in understanding these declines. Recessions are known as period of increasing uncertainty, and both firms and workers become more cautious during economic downturns: firms delay major investments and new hiring, and workers delay changing jobs or quitting without a new job in hand; see Bloom (2009). As promising as these uncertainty models might be for explaining the declining dynamics during recessions, we are still left with the puzzle of why all the measures of dynamics don't increase during expansions and return to their pre-recessionary levels.

\section{Vd. Changes in the production process}

Increasing globalization may provide an additional means of explaining the decline in U.S. labor market dynamics. If the sensitivity of U.S. production to demand shocks has 
been decreasing over time, while the sensitivity of production in other countries has been increasing, this may lead to lower employment dynamics in the U.S. This is a story of the U.S. "exporting" its production volatility and its employment dynamics to other parts of the world. Bergin, Feenstra, and Hanson (2009) provide evidence of this occurring in the production sharing relationship between U.S. manufacturers and Mexican maquiladoras (assembly plants engaged in production for foreign firms). A recent paper by Kurz and Senses (2013) looks directly at the relationship between trade and employment volatility for the U.S. manufacturing sector. Overall, this nascent literature suggests that the effects of increasing outsourcing and globalization during the past several decades may be an explanation for the declining trend in employment dynamics.

A related explanation comes from the growth of the temporary help industry. Between 1992 and 1999, the temporary help industry grew from 1.15 million employees to 2.61 million employees. The temporary help industry supplies workers to clients' businesses for limited periods of time, and thus one person who might have held many short duration jobs at different employers now can hold one job in the temporary help industry but still do the same work at different physical locations. By definition, this will result in decreased levels of employment dynamics, and is consistent with our finding from the LEHD that short-duration jobs are disappearing. But the problem with the temporary help industry being a leading explanation for declining employment dynamics is the timing - after rising in the 1990's employment in this industry has not risen since 2000 and has been procyclical since 2000.

It is possible that changing production processes during the last one to two decades has led to declining seasonality, which could lead to declining employment dynamics. We have tested all our data series for changing seasonal patterns, and we find mixed results. All three CPS series - hires, separations, and job-to-job flows, exhibit statistically significant changes in their seasonal patterns, as does the BED job creation series. For example, the difference between the CPS non-seasonally adjusted third quarter and fourth quarter job-to-job flows in the late 1990's was 1.8 percent $(9.0-7.2)$, and this difference has fallen to 0.7 percent in $2010(4.9-4.2)$. This is evidence that seasonality is diminishing in the CPS job-to-job flows series. However, none of the LEHD nor the JOLTS series shows evidence of changing seasonal patterns, and as a result, we don't view changing seasonal patterns as playing a large role in explaining declining employment dynamics.

\section{Ve. Job- and house-lock}

We would be remiss if we didn't mention job-lock and house-lock as explanations for declining job-to-job mobility. While evidence for workers keeping their jobs because they fear losing health insurance coverage for preexisting conditions exists, the magnitude of this job-lock would need to be increasing during the past 10 to 15 years, particularly in recessions, in order for it to explain the declines in job-to-job flows that are evident in the LEHD and the CPS data. We are unaware of any empirical evidence on this.

House-lock is defined as homeowners who would like to move but keep living in their current house because their mortgage exceeds the expected sale price of the house. While house-lock likely has the necessary properties to explain the recessionary declines in employment dynamics documented in this paper, there is little empirical 
evidence of house-lock preceding the Great Recession and we are unaware of any trends in increasing house-lock that would help explain the long-run secular decline.

\section{Conclusions}

We have shown that the principal measures of employment dynamics - hires and separations, job creation and job destruction, and job-to-job flows - have all declined from the late 1990's to 2010. These declines are concentrated in the recessions of 2001 and 2007-2009, from which the measures never seem to recover fully. Using four different data sources, we conducted a comprehensive accounting exercise to see whether changes in the labor market along various demographic or business characteristics could explain the decline. We found that a few characteristics could explain some of the decline, namely the aging of the population, an increase in the share of the workforce that has a Bachelor's degree, and a shift towards older firms. Some changes, such as the increase in the share of the Hispanic population and the decline in manufacturing, should raise the rate of employment dynamics, and so have an offsetting effect. However, changes in groups explains only a fraction of the decline.

Given the inability to explain the decline by shifts in the composition of individual and business characteristics, we explored a few additional methods of explaining the decline. The distribution of establishment-level employment change has been narrowing during the last 10 to 15 years, fully accounting for the decline in job creation and job destruction, yet this narrowing only explains about a third of the decline in hires and separations. This tells us that the explanation for the decline in hires and separations will be different than the explanation for the decline in job creation and job destruction. We also find that the decline in hires and separations is being driven by the decline in job-to-job flows and the disappearance of short-duration jobs in the U.S. economy.

Our motivation of this paper mentioned that declining employment dynamics could be either a good or a bad development for the U.S. labor market. Distinguishing between good or bad will depend upon understanding the source of the decline. For example, declining dynamics might be indicative of increasing adjustment costs, increasing uncertainty, or the loss of "stepping stone" jobs that help young workers begin their careers (all "bad" for the labor market). On the other hand, declining dynamics could be indicative of increasing match quality and the associated rise in wages and tenure ("good" for the labor market). Further empirical research is needed to differentiate amongst these explanations. We also believe that the secular and cyclical patterns of the employment dynamics documented in this paper need to be developed more formally so we can begin to understand the underlying source of the declining dynamics.

\section{Endnotes}

${ }^{1}$ We are not the first to note this decline. For job creation and job destruction, see Davis, Faberman, and Haltiwanger (2006), Davis et al. (2007), Konigsberg, Spletzer, and Talan (2009), Davis et al. (2010a), Haltiwanger, Jarmin, and Miranda (2011), Davis, Faberman, and Haltiwanger (2012), and Decker et al. (2013). For worker flows, see Abowd and Vilhuber (2011), Lazear and Spletzer (2012), and Davis, Faberman and Haltiwanger (2012). The decline in job-to-job flows has been noted by Bjelland et al. (2011) and Hyatt and McEntarfer (2012a, 2012b). Of these, Decker et al. (2013) is the 
only thorough attempt to explain the decline in an employment dynamics series, in their case, the annual job creation and job destruction rates from the Business Dynamics Statistics.

${ }^{2}$ Table 1 documents the decline from 1998 to 2010, which are at different points of the business cycle. However, this decline is not sensitive to endpoints, as our later figures show.

${ }^{3}$ Davis, Faberman, and Haltiwanger (2006) show a long-term fall in manufacturing job flows dating back to the early 1960's and Davis et al. (2010a) show annual privatesector job flow rates trending downward from the beginning of their series in 1977.

${ }^{4}$ We define employment dynamics as gross worker flows, gross job flows, and job-tojob flows, and therefore exclude other measures of employment transitions that have also exhibited declines. See Fujita (2012) and Cairo and Cajner (2013) for evidence of a decline in the CPS unemployment inflow rate over the last three decades. Molloy, Smith, and Wozniak $(2011,2013)$ and Kaplan and Schulhofer-Wohl (2012) document a decline in interstate migration over the same time period. Moscarini and Thomsson (2007) document an increase in occupational mobility from the late 1970's to the mid1990's followed by a decline after 1994 .

${ }^{5}$ We omit the Business Dynamics Statistics (BDS) from our core analysis because its data are annual whereas all others can be analyzed on a quarterly frequency. The BDS also shows a declining trend in job creation and job destruction in the time period we consider; this declining trend is analyzed by Decker et al. (2013) using the underlying confidential microdata.

${ }^{6}$ Our estimates of the magnitude of the decline in employment dynamics are essentially unaffected when we use the national series of LEHD hires, separations, job creation, and job destruction constructed by Abowd and Vilhuber (2011).

${ }^{7}$ The LEHD job-to-job flows data include state and local government, whereas our LEHD gross worker and job flows exclude government. Similarly, the BED and JOLTS data that we use exclude government, whereas the CPS gross flows that we use include state, local, and federal government. We make these choices in order to use the data that are publicly available to researchers. Empirical results using available data show that the double-digit percentage declines in employment dynamics measured over the past 10 to 15 years are unaffected by the inclusion or exclusion of government jobs.

${ }^{8}$ Each decomposition requires categorization of a given variable. Worker Age has 6 categories: $\{<24,25-34,35-44,45-54,55-64,65+\}$. Gender has 2 categories: $\{$ male, female\}. Race \& Ethnicity has 5 categories: \{Asian non-Hispanic, Black non-Hispanic, White non-Hispanic, Other non-Hispanic, Hispanic\}. Education has 4 categories: \{less than high school, high school graduate, some college, college graduate\}; the education sample is restricted to persons aged 25+. Industry has 11 categories: \{Mining, Construction, Manufacturing, Wholesale \& Retail Trade, Transportation and Utilities, Information, Financial Activities, Professional and Business Services, Education \& Health Services, Leisure and Hospitality Services, Other Services\}. Firm Size has 5 categories: $\{<20,20-49,50-249,250-499, \geq 500\}$. Establishment Size has 3 categories: $\{<50,50-$ $249, \geq 250\}$. Firm Age has 5 categories: $\{0-1,2-3,4-5,6-10,11+\}$.

${ }^{9}$ The employment share of Asian non-Hispanics has increased from 5.1 percent to 6.2 percent, the employment share of Hispanics has increased from 13.5 percent to 15.8 percent, and the employment share of White non-Hispanics has decreased from 68.2 percent to 64.7 percent. 
${ }^{10}$ The education results in the LEHD data are essentially zero, which we believe is an artifact of how the education data in the LEHD are created rather than a true economic result. Educational information is not part of the UI wage records, but is obtained from a link to the long form of the 2000 Decennial Census. As of 2013, the LEHD program uses Census 2000 long-form responses for the population age 25 and over as the sampling distribution for worker education, and allows no variation over time in any worker's educational attainment. As a result, the time series of employment shares by education in the LEHD do not show nearly as much of a trend toward bachelor's degree attainment as does the CPS, and this lack of time series variation leads to LEHD's zero effect from composition changes in education.

${ }^{11}$ The share of employment in firms aged $0-1$ years has fallen by 1.9 percent over the 1998:Q2 to 2010:Q4 time period, and the share of employment in firms aged 2-3 years has fallen by 1.3 percent. The share of employment in firms more than 10 years of age has increased by 4.5 percent. Hires and separations are declining in magnitude with the age of the firm.

${ }^{12}$ The exact bins we use are $\{-2,(-2.0,-1.5),[-1.5,-1.25),[-1.25,-1),[-1,-.9), \ldots .,[-.3,-.2)$, $[-.2,-.18), \ldots,[-.12,-.1),[-.1,-.09), \ldots .,[-.01,0), 0,(0, .01], \ldots,(.09, .1],(.1, .12], \ldots .,(.18, .2]$, $(.2,3], \ldots,(.9,1],(1,1.25],(1.25,1.5],(1.5,2), 2\}$.

${ }^{13}$ Figure 4 is asymmetric in that it shows more contractions than expansions. We believe that this is due to the change in the business cycle when comparing 1998:Q2 to 2010:Q4. Re-creating Figure 4 using similar points in the business cycle, such as comparing 2000:Q4 to 2007:Q4 and comparing 2003:Q3 to 2010:Q3, shows no substantial asymmetry.

${ }^{14}$ Graphs similar to Figure 5 which show the hires and separations rates for quarters at similar peaks of the business cycle during the 1998 to 2010 time period are visually identical to Figure 5.

\footnotetext{
Competing interests

The IZA Journal of Labor Economics is committed to the IZA Guiding Principles of Research Integrity. The authors declare that they have observed these principles.
}

\begin{abstract}
Acknowledgements
Any opinions and conclusions expressed herein are those of the authors and do not necessarily represent the views of the U.S. Census Bureau. All results have been reviewed to ensure that no confidential information is disclosed. We are very grateful to Bruce Fallick for providing us with tabulations by demographics and industry from the CPS gross flows series. We thank J. David Brown, Fariha Kamal, David Card, Leland Crane, Steve Davis, Bruce Fallick, Lucia Foster, John Haltiwanger, Kristin McCue, Erika McEntarfer, Hiroaki Miyamoto, Lars Vilhuber, the editor Joseph Hotz, four anonymous referees, and participants at various conferences and seminars for helpful comments and suggestions. Responsible Editor: V. Joseph Hotz
\end{abstract}

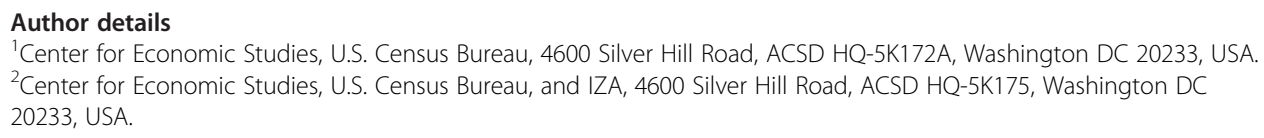

${ }^{1}$ Center for Economic Studies, U.S. Census Bureau, 4600 Silver Hill Road, ACSD HQ-5K172A, Washington DC 20233, USA. ${ }^{2}$ Center for Economic Studies, U.S. Census Bureau, and IZA, 4600 Silver Hill Road, ACSD HQ-5K175, Washington DC 20233, USA.

Received: 2 July 2013 Accepted: 20 August 2013

Published: 20 Sep 2013

\title{
References
}

Abowd JM, Vilhuber L (2011) National Estimates of Gross Employment and Job Flows from the Quarterly Workforce Indicators with Demographic and Industry Detail. J Econometrics 161(1):82-99

Abowd JM, Stephens BE, Vilhuber L, Andersson F, McKinney KL, Roemer M, Woodcock S (2009) The LEHD Infrastructure Files and the Creation of the Quarterly Workforce Indicators. In: Dunne TJ, Jensen JB, Roberts MJ (eds) Producer Dynamics: New Evidence from Micro Data. University of Chicago Press, Chicago IL

Abraham KG, Haltiwanger J, Sandusky K, Spletzer JR (2013) Exploring Differences in Household vs. Establishment Measures of Employment. J Labor Econ 31(2, pt. 2):S129-S172

Autor DH (2001) Wiring the Labor Market. J Econ Perspect 15(1):25-40 
Bergin PR, Feenstra RC, Hanson GH (2009) Offshoring and Volatility: Evidence from Mexico's Maquiladora Industry. Am Econ Rev 99(4):1664-1671

Bjelland MJ, Fallick B, Haltiwanger JC, McEntarfer EL (2011) Employer-to-Employer Flows in the United States: Estimates Using Linked Employer-Employee Data. J Bus Econ Stat 29(4):493-505

Bloom N (2009) The Impact of Uncertainty Shocks. Econometrica 77(3):623-685

Burdett K (1978) A Theory of Employee Job Search and Quit Rates. Am Econ Rev 68(1):212-220

Cairo I, Cajner T (2013) The Fading Dynamism of the US Labor Market: The Role of Demographics. Unpublished paper, Board of Governors of the Federal Reserve System., http:/www.eea-esem.com/files/papers/EEA-ESEM/2013/2907/ Cairo_Cajner-Fading_Dynamism_Demographics.pdf (accessed August 13, 2013)

Davis SJ, Haltiwanger JC, Schuh S (1996) Job Creation and Destruction. MIT Press, Cambridge MA

Davis SJ, Faberman RJ, Haltiwanger JC (2006) The Flow Approach to Labor Markets, Micro-macro Links, and the Recent Downturn. J Econ Perspect 20(3):3-26

Davis SJ, Haltiwanger JC, Jarmin RS, Miranda J (2007) Volatility and Dispersion in Business Growth Rates: Publicly Traded and Privately Held Firms. In: Acemoglu D, Rogoff K, Woodford M (eds) NBER Macroeconomics Annual, vol 21. MIT Press, Cambridge MA

Davis SJ, Faberman RJ, Haltiwanger JC, Jarmin RS, Miranda J (2010a) Business Volatility, Job Destruction and Unemployment. Am Econ J Macroecon 2(2):259-287

Davis SJ, Faberman RJ, Haltiwanger JC, Rucker I (2010b) Adjusted Estimates of Worker Flows and Job Openings in JOLTS. In: Abraham KG, Spletzer JR, Harper MJ (eds) Labor in the New Economy. University of Chicago Press, Chicago IL

Davis SJ, Faberman RJ, Haltiwanger JC (2012) Labor Market Flows in the Cross Section and over Time. J Monetary Econ 59(1):1-18

Decker R, Haltiwanger JC, Jarmin RS, Miranda J (2013) The Secular Decline in Business Dynamism in the U.S., Unpublished paper, University of Maryland, http://econweb.umd.edu/ haltiwan/DHJM_JEP_5_17_2013.pdf (accessed September 4, 2013)

Fallick B, Fleischman C (2004) Employer-to-Employer Flows in the U.S. Labor Market: The Complete Picture of Gross Worker Flows. Finance and Economics Discussion Series \#2004-34, Board of Governors of the Federal Reserve System., http://www.federalreserve.gov/pubs/feds/2004/200434/200434pap.pdf (accessed August 13, 2013)

Foster LS, Haltiwanger JC, Krizan CJ (2001) Aggregate Productivity Growth: Lessons from Microeconomic Evidence. In: Dean E, Harper M, Hulten C (eds) New Directions in Productivity Analysis. University of Chicago Press, Chicago IL

Fujita S (2012) Declining Labor Turnover and Turbulence. Federal Reserve Bank of Philadelphia Working Paper \#11-44/ R., http://www.philadelphiafed.org/research-and-data/publications/working-papers/2011/wp11-44R.pdf (accessed August 13, 2013)

Haltiwanger JC, Jarmin RS, Miranda J (2011) Historically Large Decline in Job Creation from Startup and Existing Firms in the 2008-2009 Recession. Statistical Brief for the Kauffman Foundation, http://www.kauffman.org/uploadedFiles/ bds_report_3-22-11.pdf (accessed August 13, 2013)

Hyatt HR, McEntarfer EL (2012a) Job-to-Job Flows in the Great Recession. Am Econ Rev 102(3):580-583

Hyatt HR, McEntarfer EL (2012b) Job-to-Job Flows and the Business Cycle. Center for Economic Studies Working Paper \#12-04, U.S., Census Bureau, ftp://ftp2.census.gov/ces/wp/2012/CES-WP-12-04.pdf (accessed August 13, 2013)

Hyatt HR, Spletzer JR (2013) The Recent Decline in Employment Dynamics. IZA Discussion Paper \#7231., http://ftp.iza. org/dp7231.pdf (accessed August 13, 2013)

Jovanovic B (1979) Job Matching and the Theory of Turnover. J Polit Econ 87(5):972-990

Jovanovic B (1982) Selection and the Evolution of Industry. Econometrica 50(3):649-670

Jovanovic B, Moffitt R (1990) An Estimate of a Sectoral Model of Labor Mobility. J Polit Econ 98(4):827-852

Kaplan G, Schulhofer-Wohl S (2012) Understanding the Long-Run Decline in Interstate Migration. NBER Working Paper \#18507., http://www.nber.org/papers/w18507.pdf (accessed August 13, 2013)

Konigsberg SL, Spletzer JR, Talan DM (2009) Business Employment Dynamics: Tabulations by Size of Employment Change. Mon Labor Rev 132(4):19-29

Kurz C, Senses MZ (2013) Trading Firms and Volatility. Finance and Economics Discussion Series \#2013-44, Board of Governors of the Federal Reserve System., http://www.federalreserve.gov/pubs/feds/2013/201344/201344pap.pdf (accessed August 13, 2013)

Lazear EP, Spletzer JR (2012) Hiring, Churn, and the Business Cycle. Am Econ Rev 102(3):575-579

MacLeod WB (2011) Great Expectations: Law, Employment Contracts, and Labor Market Performance. In: Ashenfelter O, Card D (eds) Handbook of Labor Economics, vol 4. Elsevier, London

Manning A (2011) Imperfect Competition and the Labour Market. In: Ashenfelter O, Card D (eds) Handbook of Labor Economics, vol 4. Elsevier, London

Michau JB (2013) Creative Destruction with On-the-Job Search. Rev Econ Dynam. doi:10.1016/j.red.2012.10.011

Miyamoto H, Takahashi Y (2011) Productivity Growth, On-the-Job Search, and Unemployment. J Monetary Econ 58(6):666-680

Molloy R, Smith CL, Wozniak AK (2011) Internal Migration in the United States. J Econ Perspect 25(3):173-196

Molloy R, Smith CL, Wozniak AK (2013) Declining Migration Within the US: The Role of the Labor Market. Finance and Economics Discussion Series \#2013-27, Board of Governors of the Federal Reserve System., http://www. federalreserve.gov/pubs/feds/2013/201327/201327pap.pdf (accessed August 13, 2013)

Moscarini G, Postel-Vinay F (2013) Stochastic Search Equilibrium. Rev Econ Stud. doi:10.1093/restud/rdt012

Moscarini G, Thomsson K (2007) Occupational and Job Mobility in the US. Scand J Econ 109(4):807-836

Topel RH, Ward MP (1992) Job Mobility and the Careers of Young Men. Q J Econ 107(2):439-479

10.1186/2193-8997-2-5

Cite this article as: Hyatt and Spletzer: The recent decline in employment dynamics. IZA Journal of Labor Economics 2013, 2:5 